\title{
Flint artefacts from the Wielbark culture cemetery at Weklice, Site 7, Elbląg county
}

\author{
Magdalena Natuniewicz-Sekuła ${ }^{1}$, Dagmara H. Werra ${ }^{2}$
}

1. Institute of Archaeology and Ethnology Polish Academy of Sciences, Medieval Archaeology Centre of the Baltic Lands, Al. Solidarności 105, PL 00-140 Warsaw, Poland. Email: m_natuniewicz@yahoo.com

2. Institute of Archaeology and Ethnology Polish Academy of Sciences, Autonomous Research Laboratory for Prehistoric Flint Mining, Al. Solidarności 105, PL 00-140 Warsaw, Poland. Email: werra@iaepan.edu.pl

\begin{abstract}
:
In the Bronze Age flint was still being used throughout Europe. In the early periods of that age flint continued to play an important role in the economy in many areas, as evidenced by the numerous flint mines in use at the time as well as flint tools. In the Late Bronze and Early Iron Ages, flint still had an important place in the economies of communities living in East Central Europe. At the same time, analysis of late flint industries suggests that some of those had no utilitarian significance. The presence of flint, especially in inhumation graves from the cemetery at Weklice (used by communities of the Wielbark culture during the Roman Period) potentially adds to the debate about its significance. The cemetery at Weklice is the one of the best-known sites from the Roman Period in Poland. The graves are mostly equipped with local finds of metals: gold, silver, copper alloys, iron and amber as well as Roman imports (glass beads, vessels: glass, copper alloys). The collections comprise over of 4000 finds, however this number may change, as excavations in 2012 and 2013 revealed 22 flint artefacts. The presence of flint materials in a Roman Period cemetery admits several possible interpretations: 1) Those may be remnants of older settlements, with graves being dug into older strata and thus some of the specimens of flint could be in their secondary filling on the site; 2) Those may be remains of flint knapping activity by the Wielbark culture community; 3) Those may have been placed in the graves deliberately by the Wielbark culture community as an instance of an older custom involving the placing of flint in graves.
\end{abstract}

Keywords: flints; Roman period; Wielbark culture; cemetery; northeastern Poland

\section{Introduction}

As discussed in the literature on numerous occasions, the necropolis at Weklice (see Figure 1) - for further literature confer Natuniewicz-Sekuła \& Okulicz-Kozaryn (2011) - may be considered a canon archaeological site from the Roman Period - mainly due to the diversity of materials discovered at the site, not all of which come from the Wielbark culture, as shown by researches in recent years.

Published by the School of History, Classics and Archaeology, University of Edinburgh ISSN: 2055-0472. URL: http://journals.ed.ac.uk/lithicstudies/

This work is licensed under a Creative Commons Attribution 2.5 UK: Scotland License. 


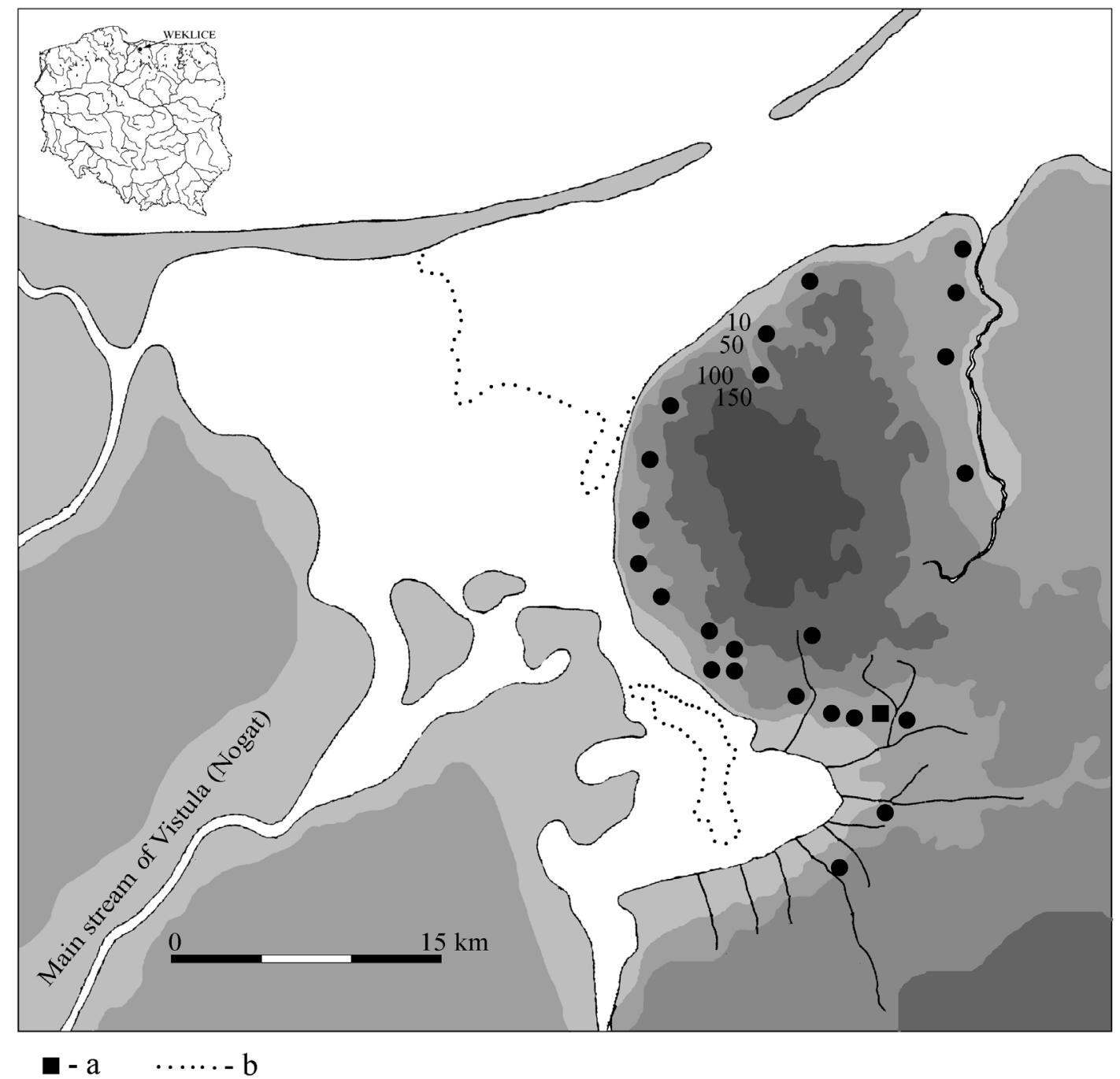

Figure 1. Reconstruction of the Vistula delta during the Roman Period with main sites of the Wielbark culture on the Elbląg Heights: a. location of Weklice cemetery, b. today's extent of the Vistula Lagoon and Drużno Lake. (Prepared by M. Natuniewicz-Sekuła.)

This article presents a collection of 22 flint artefacts (see Table 1 and Figures 2 to 4). The finds were discovered during the 2012 and 2013 seasons. All of the finds were uncovered in the context of inhumation graves from the Wielbark culture. The first flint materials were discovered during the 2012 season in grave 579, which was located on the southwestern edge of the then excavation trench. The elements of inventory included: a wooden staves bucket with copper alloy fittings (yew-tree; as defined by Maria Michniewicz from the Bio- and Archaeometry Laboratory, Institute of Archaeology and Ethnology Polish Academy of Sciences - further: IAE PAN), three clay vessels (two wheel-made); an amber necklace with amber eight-shape beads made on a lathe, and a spinning set consisting of a silver needle, a silver hook pin with twisted shaft as well as amber spindle whorl. Flints were found in the concentration of items connected with a distaff, and were thus initially interpreted as a collection of tools associated with this manufacture. It has to be noted that only teeth laminae had been preserved of the skeletal bones, but the character of the objects found in the grave suggests that the buried individual was female. The remaining ones were discovered in 2013 west of the 2012 excavation trench. Flint assemblages were also found in graves and features (nos. 586, 587, 588, 590, and feature 590A - an ancient robbery trench in grave 590) as well as below the bottom of grave pits (see Table 1, where the absolute position of the flint assemblages and grave features is stated in meters above sea level). 

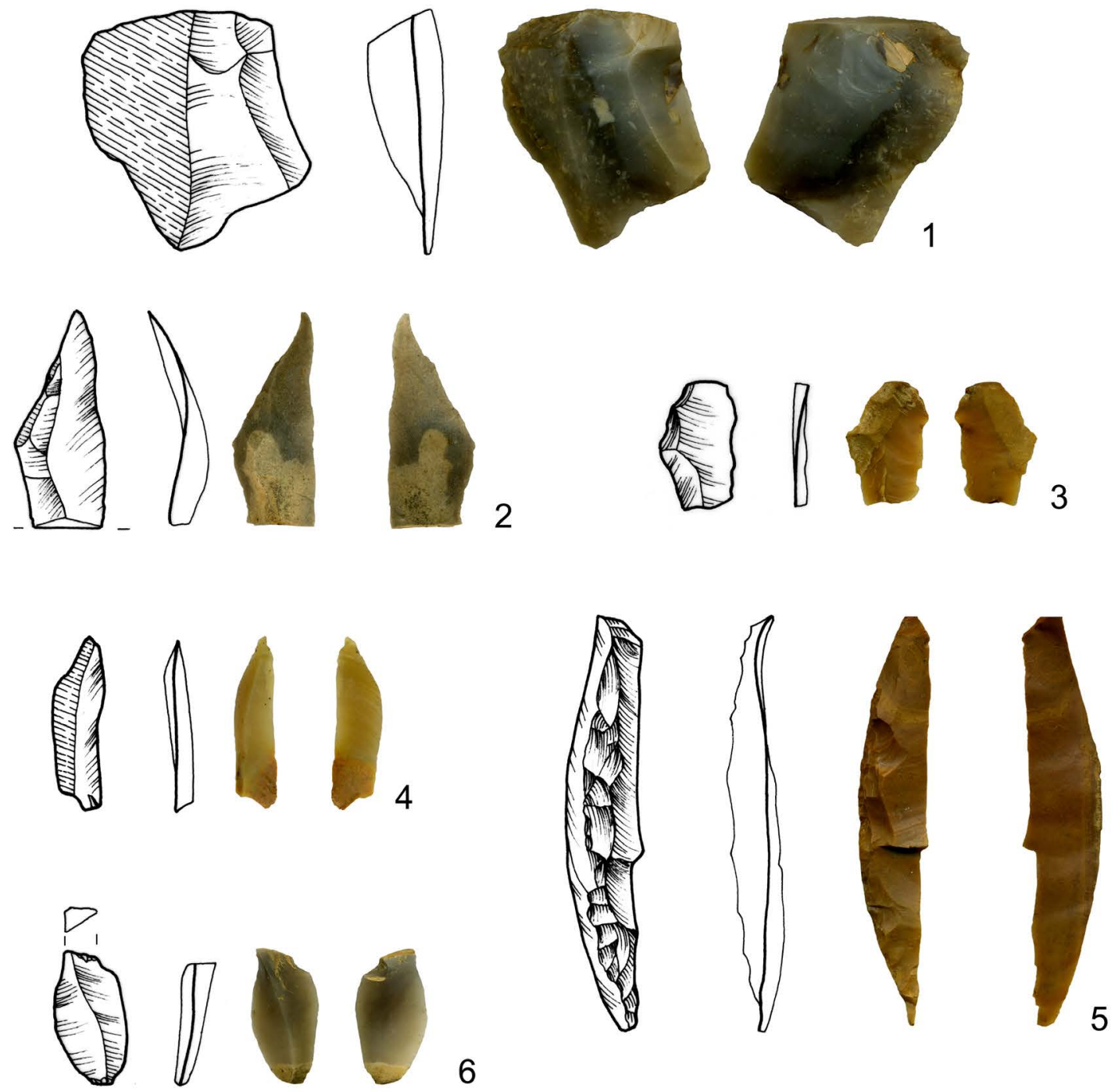

6
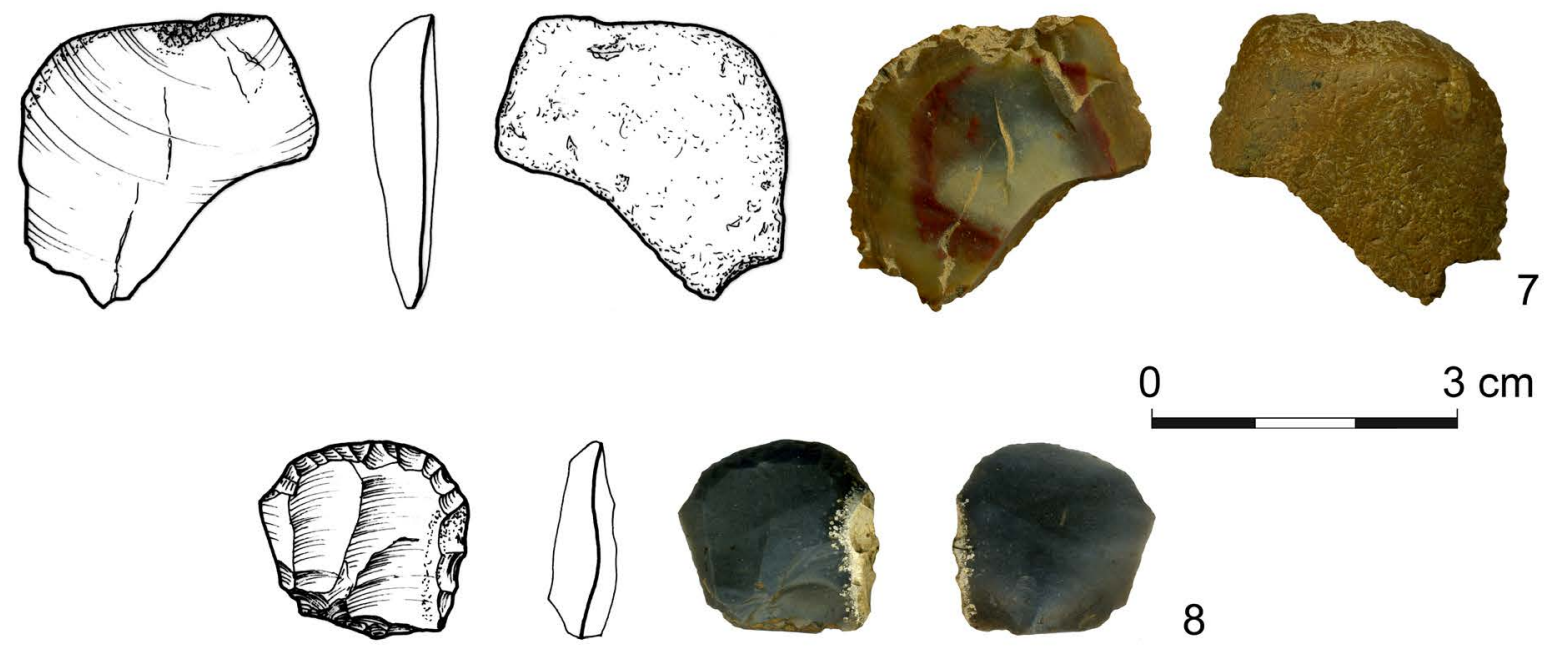

Figure 2. Weklice, Elbląg county. Flint artefacts: 1. flake with negative flake scars on the dorsal surface; 2. fragment of a blade with scars on the dorsal surface; 3. flake with negative flake scars on the dorsal surface; 4 . blade with scars on the dorsal surface; 5 . secondary crested blade; 6 . flake with negative flake scars on the dorsal surface; 7. initial flake; 8. endscraper. (Drawing by E. Gumińska, E. Pazyna and D. H. Werra. Photo by M. Natuniewicz-Sekuła.) 
Table 1. Inventory of flint artefacts from the cemetery at Weklice, Elbląg County. Numbers correspond to Figures 2 to 4 . Abbreviations: Dp - depth (m A.S.L.); GD - Grave, feature depth below ground level (m); Wt - weight (g); L - length (mm); Wd - width (mm); T - thickness (mm); Dm - diameter (mm); Fig. - figure. (Elaborated by D. H.

\begin{tabular}{|c|c|c|c|c|c|c|c|c|c|c|c|c|c|}
\hline No. & $\begin{array}{l}\text { Inv. } \\
\text { no. }\end{array}$ & $\begin{array}{c}\text { Trench/layer; } \\
\text { Ar/square }\end{array}$ & $\begin{array}{c}D \\
(m)\end{array}$ & $\begin{array}{c}\text { Grave, } \\
\text { feature }\end{array}$ & $\begin{array}{l}\text { GD } \\
(\mathrm{m})\end{array}$ & Raw material & Description & $\begin{array}{l}W \\
(g)\end{array}$ & $\begin{array}{c}\mathrm{L} \\
(\mathrm{mm})\end{array}$ & $\begin{array}{c}W \\
(\mathrm{~mm})\end{array}$ & $\begin{array}{c}\mathrm{T} \\
(\mathrm{mm})\end{array}$ & $\begin{array}{c}D \\
(\mathrm{~mm})\end{array}$ & Fig. \\
\hline 1 & 3300 & $\begin{array}{l}\text { II/[194A }] ; 17- \\
\text { 20/B }\end{array}$ & 29.29 & 579 & 2 & Baltic flint & $\begin{array}{l}\text { Flake with negative flake scars on the dorsal } \\
\text { surface; prepared butt - single strike }\end{array}$ & 6.4 & 30 & 26 & 9 & 32 & 2.1 \\
\hline 2 & & & & & & Baltic flint & $\begin{array}{l}\text { Blade with scars on the entire dorsal surface; } \\
\text { with broken platform part }\end{array}$ & 0.8 & 27 & 11 & 3 & 28 & 2.2 \\
\hline 3 & & & & & & Pomeranian flint & $\begin{array}{l}\text { Flake with negative flake scars on the dorsal } \\
\text { surface; prepared butt - single strike }\end{array}$ & 0.2 & 16 & 11 & 1 & 16 & 2.3 \\
\hline 4 & & & & & & Pomeranian flint & $\begin{array}{l}\text { Blade with scars on the entire dorsal surface, } \\
\text { punctuated butt }\end{array}$ & 0.3 & 22 & 6 & 2 & 22 & 2.4 \\
\hline 5 & 3362 & $\begin{array}{l}\text { II/[100B }] ; 17- \\
\text { 20/D }\end{array}$ & 29.05 & $\begin{array}{c}586 \\
\text { (under) }\end{array}$ & 2.2 & Pomeranian flint & $\begin{array}{l}\text { Secondary crested blade with, broken } \\
\text { platform part }\end{array}$ & 2.6 & 52 & 9 & 5 & 52 & 2.5 \\
\hline 6 & 3363 & $\begin{array}{l}\text { II/[100B]; } 17- \\
\text { 20/D }\end{array}$ & 29.06 & $\begin{array}{c}586 \\
\text { (under) }\end{array}$ & 2.2 & Baltic flint & $\begin{array}{l}\text { Flake with negative flake scars on the dorsal } \\
\text { surface, natural butt }\end{array}$ & 0.5 & 17 & 9 & 4 & 18 & 2.6 \\
\hline 7 & 3364 & $\begin{array}{l}\text { II/[100B }] ; 17- \\
\text { 20/D }\end{array}$ & 28,91 & $\begin{array}{c}586 \\
\text { (under) }\end{array}$ & 2.2 & Pomeranian flint & Initial flake, bipolar technique & 6 & 28 & 31 & 6 & 34 & 2.7 \\
\hline 8 & 3365 & $\begin{array}{l}\text { II/[100B }] ; 17- \\
\text { 20/D }\end{array}$ & 28.85 & $\begin{array}{c}586 \\
\text { (under) }\end{array}$ & 2.2 & Baltic flint & Endscraper & 2.3 & 19 & 20 & 5 & 22 & 2.8 \\
\hline 9 & 3366 & $\begin{array}{l}\text { II/[100B }] ; 17- \\
\text { 20/D }\end{array}$ & 28.80 & $\begin{array}{c}586 \\
\text { (under) }\end{array}$ & 2.2 & Baltic flint & $\begin{array}{l}\text { Flake with negative flake scars on the dorsal } \\
\text { surface, prepared butt }\end{array}$ & 0.5 & 12 & 18 & 3 & 20 & 3.9 \\
\hline 10 & 3367 & $\begin{array}{l}\text { II/[100B }] ; 17- \\
\text { 20/D }\end{array}$ & 28.80 & $\begin{array}{c}586 \\
\text { (under) }\end{array}$ & 2.2 & Baltic flint & $\begin{array}{l}\text { Middle part of blade with scars on the entire } \\
\text { dorsal surface, with retouched platform part }\end{array}$ & 0.8 & 27 & 14 & 2 & 29 & 3.10 \\
\hline 11 & 3368 & $\begin{array}{l}\text { II/[100B }] ; 17- \\
\text { 20/D }\end{array}$ & 28.77 & 586 & 2.2 & Baltic flint & Partly initial microflake & 0.4 & 16 & 8 & 4 & 16 & 3.11 \\
\hline 12 & 3369 & $\begin{array}{c}\mathrm{II} /[217 \mathrm{~A}] ; 17- \\
20 / \mathrm{C}\end{array}$ & 29.49 & 588 & 2.3 & $\begin{array}{l}\text { Cretaceous flint } \\
\text { (possibly Volhynian } \\
\text { flint) }\end{array}$ & $\begin{array}{l}\text { Retouched blade; prepared striking platform; } \\
\text { pressure technique }\end{array}$ & 23 & 118 & 17 & 9 & 118 & 3.12 \\
\hline 13 & 3374 & $\begin{array}{l}\mathrm{II} /[100 \mathrm{~B}] ; 17- \\
20 / \mathrm{D}\end{array}$ & 28.85 & $\begin{array}{c}587 \\
\text { (under) }\end{array}$ & 2.2 & Baltic flint & $\begin{array}{l}\text { Blade with scars on the entire dorsal surface, } \\
\text { prepared butt, platform edge trimming; visible } \\
\text { "lip"; pressure technique }\end{array}$ & 0.4 & 29 & 8 & 2 & 29 & 3.13 \\
\hline 14 & 3378 & $\begin{array}{l}\mathrm{II} /[219 \mathrm{~B}] ; 17- \\
20 / \mathrm{D}\end{array}$ & 29.04 & $590 A$ & 2.35 & Baltic flint & flake fragment & 5.8 & - & - & - & 38 & 4.14 \\
\hline
\end{tabular}




\begin{tabular}{|c|c|c|c|c|c|c|c|c|c|c|c|c|c|}
\hline No. & $\begin{array}{l}\text { Inv. } \\
\text { no. }\end{array}$ & $\begin{array}{l}\text { Trench/layer; } \\
\text { Ar/square }\end{array}$ & $\begin{array}{c}D \\
(m)\end{array}$ & $\begin{array}{l}\text { Grave, } \\
\text { feature }\end{array}$ & $\begin{array}{l}\text { GD } \\
(\mathrm{m})\end{array}$ & Raw material & Description & $\begin{array}{l}W \\
(g)\end{array}$ & $\begin{array}{c}\mathrm{L} \\
(\mathrm{mm})\end{array}$ & $\begin{array}{c}W \\
(\mathrm{~mm})\end{array}$ & $\begin{array}{c}\mathrm{T} \\
(\mathrm{mm})\end{array}$ & $\begin{array}{c}D \\
(\mathrm{~mm})\end{array}$ & Fig. \\
\hline 15 & 3379 & $\begin{array}{l}\mathrm{II} /[219 \mathrm{~B}] ; 17- \\
20 / \mathrm{D}\end{array}$ & 29.11 & $590 \mathrm{~A}$ & 2.35 & Pomeranian flint & initial flake & 2.4 & 16 & 26 & 6 & 26 & 4.15 \\
\hline 16 & 3380 & $\begin{array}{l}\mathrm{II} /[100 \mathrm{~B}] ; 17- \\
\text { 20/D }\end{array}$ & 28.97 & $\begin{array}{c}590 \mathrm{~A} \\
\text { (under) }\end{array}$ & 2.35 & Baltic flint & partially initial blade; prepared butt & 1.4 & 30 & 9 & 4 & 30 & 4.16 \\
\hline 17 & 3381 & $\begin{array}{l}\text { II/[100B }] ; 17- \\
\text { 20/D }\end{array}$ & 28.94 & $\begin{array}{c}590 A \\
\text { (under) }\end{array}$ & 2.35 & Pomeranian flint & $\begin{array}{l}\text { blade with scars on the entire dorsal surface; } \\
\text { punctuated butt; crested blade }\end{array}$ & 1.9 & 36 & 13 & 4 & 36 & 4.17 \\
\hline 18 & 3382 & $\begin{array}{l}\mathrm{II} /[100 \mathrm{~B}] ; 17- \\
20 / \mathrm{D}\end{array}$ & 28.91 & $\begin{array}{c}590 \mathrm{~A} \\
\text { (under) }\end{array}$ & 2.35 & Baltic flint & $\begin{array}{l}\text { blade with scars on the entire dorsal surface; } \\
\text { with broken platform part and tip }\end{array}$ & 0.8 & 29 & 10 & 3 & 29 & 4.18 \\
\hline 19 & 3383 & $\begin{array}{l}\text { II/[100B }] ; 17- \\
\text { 20/D }\end{array}$ & 28.76 & $\begin{array}{c}586 \\
\text { (under) }\end{array}$ & 2.2 & Baltic flint & Partially initial flake, prepared butt & 0.9 & 23 & 12 & 3 & 23 & 4.19 \\
\hline 20 & 3384 & $\begin{array}{l}\text { II/[100B }] ; 17- \\
\text { 20/D }\end{array}$ & 28.75 & $\begin{array}{c}586 \\
\text { (under) }\end{array}$ & 2.2 & Baltic flint? & $\begin{array}{l}\text { Microflake with negative flake scars on the } \\
\text { dorsal surface; prepared butt }\end{array}$ & 0.4 & 12 & 11 & 3 & 14 & 4.20 \\
\hline 21 & 3385 & $\begin{array}{l}\text { II/[100B]; } 17- \\
\text { 20/D }\end{array}$ & 28.74 & $\begin{array}{c}586 \\
\text { (under) }\end{array}$ & 2.2 & Baltic flint & $\begin{array}{l}\text { Flake with negative flake scars on the dorsal } \\
\text { surface, prepared butt; fire-strike? }\end{array}$ & 0.8 & 12 & 19 & 4 & 19 & 4.21 \\
\hline 22 & 3386 & $\begin{array}{l}\text { II/[100B }] ; 17- \\
20 / D\end{array}$ & 28.72 & $\begin{array}{c}586 \\
\text { (under) }\end{array}$ & 2.2 & Baltic flint & $\begin{array}{l}\text { Flake with negative flake scars on the dorsal } \\
\text { surface, punctuated butt }\end{array}$ & 1.7 & 24 & 20 & 4 & 24 & 4.22 \\
\hline
\end{tabular}



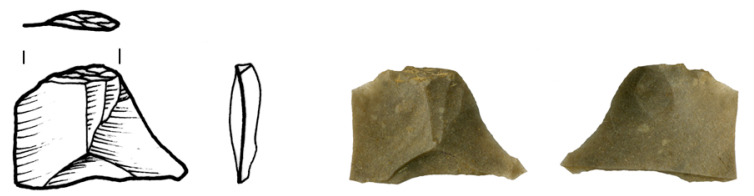

9
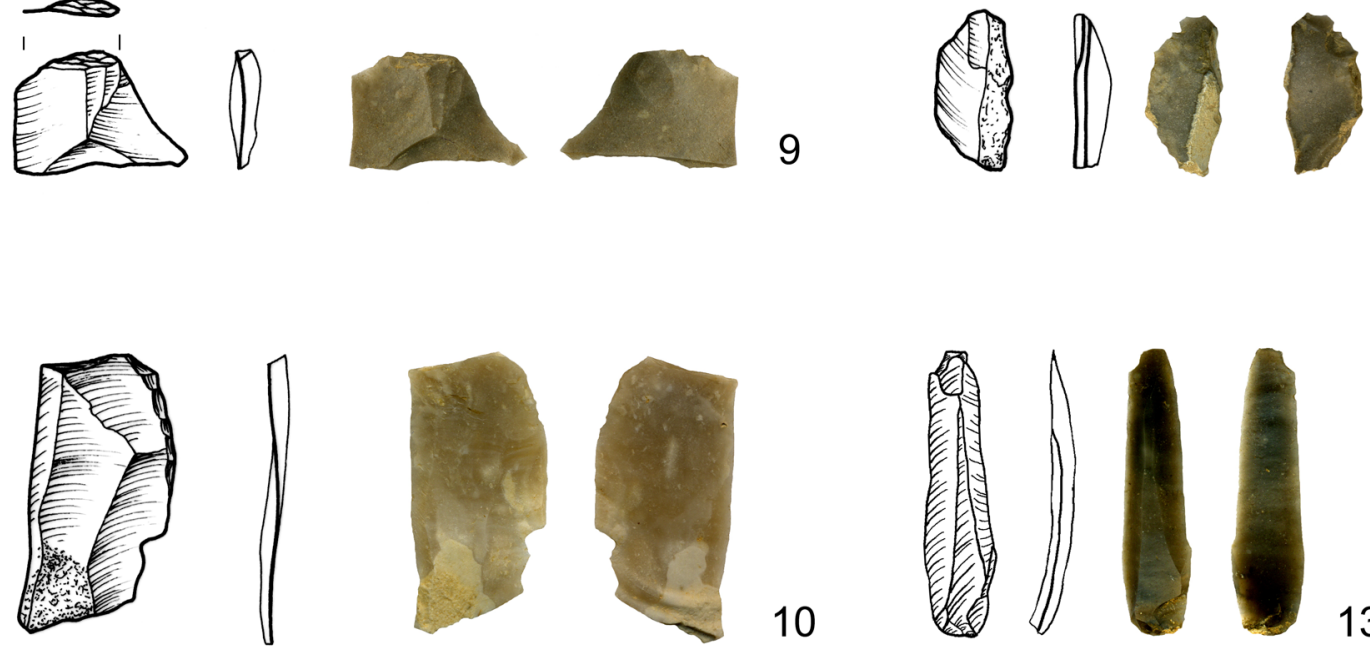

10
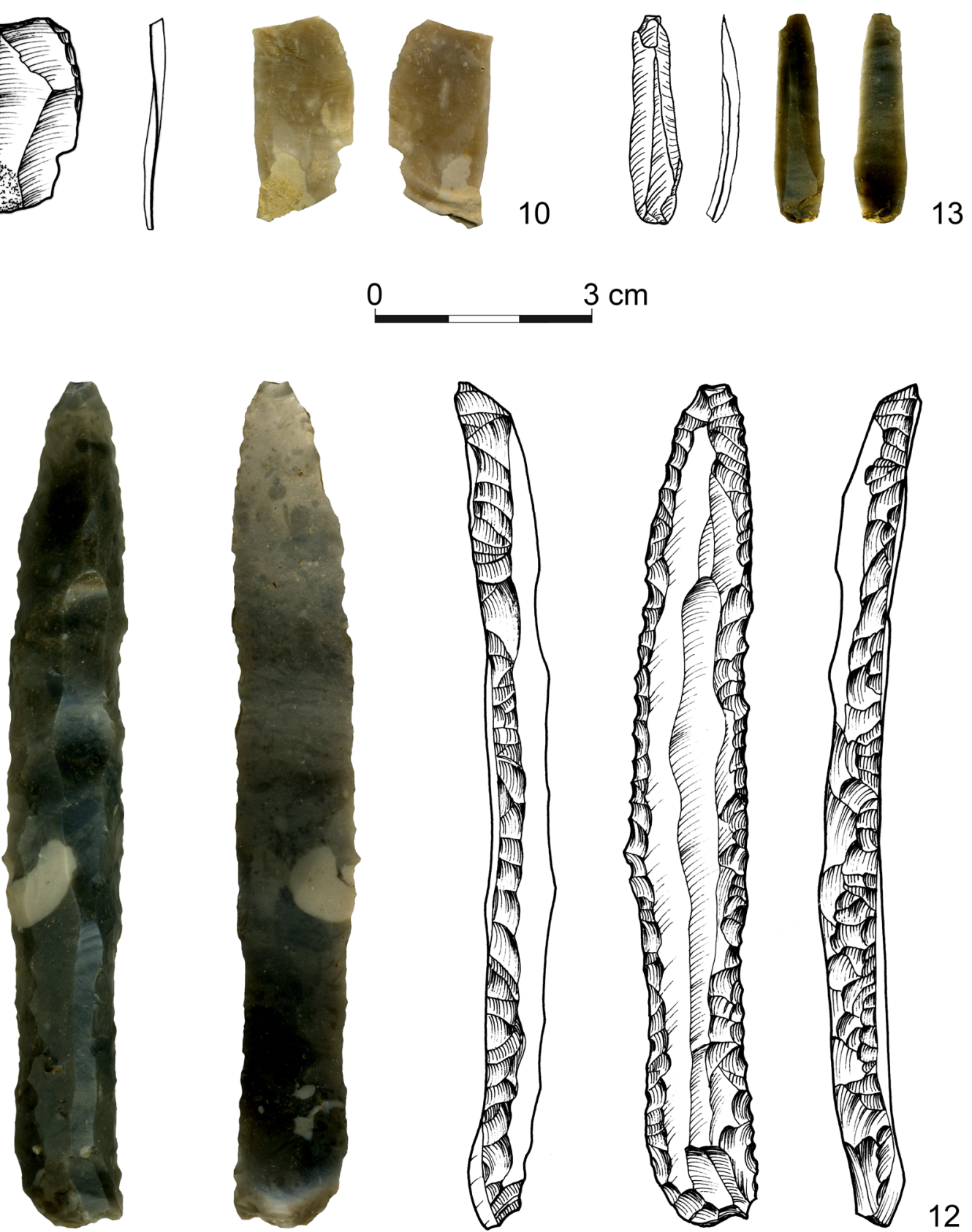

Figure 3. Weklice, Elbląg county. Flint artefacts: 9. flake with negative flake scars on the dorsal surface; 10. mesial fragment of blade with scars on the dorsal surface; 11. partially initial microflake; 12. retouched blade; 13. blade with scars on the entire dorsal surface. (Drawing by E. Gumińska, E. Pazyna and D. H. Werra. Photo by M. Natuniewicz-Sekuła.) 

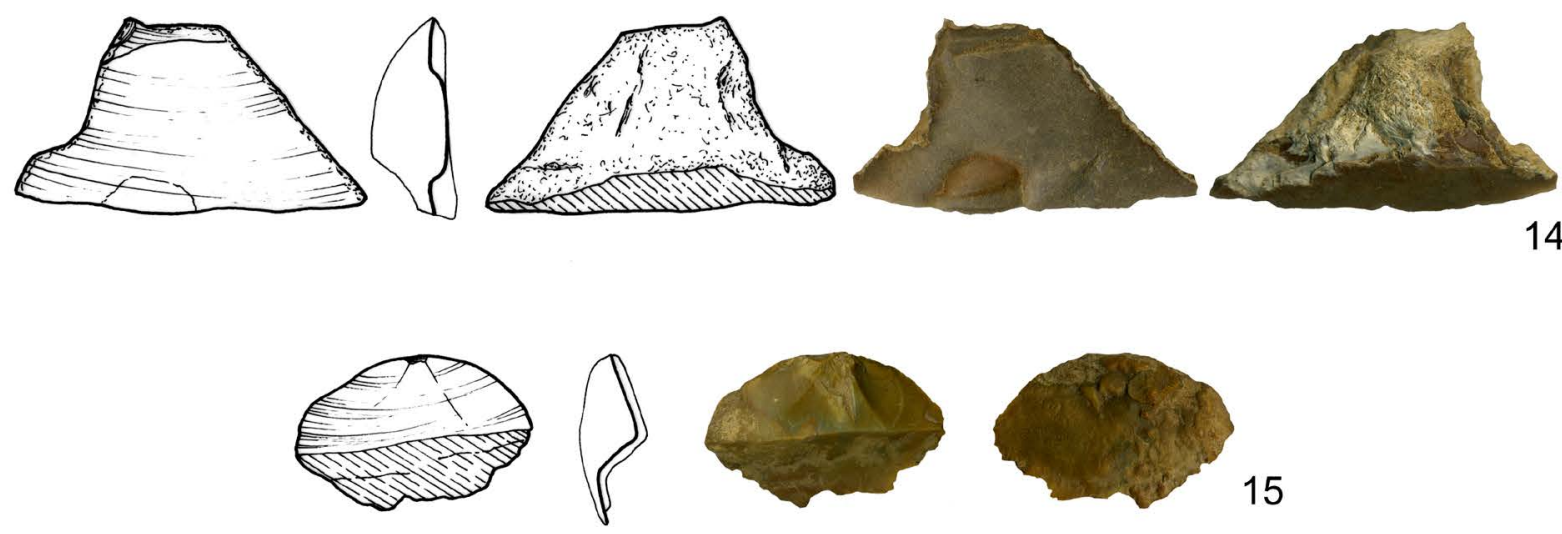

15
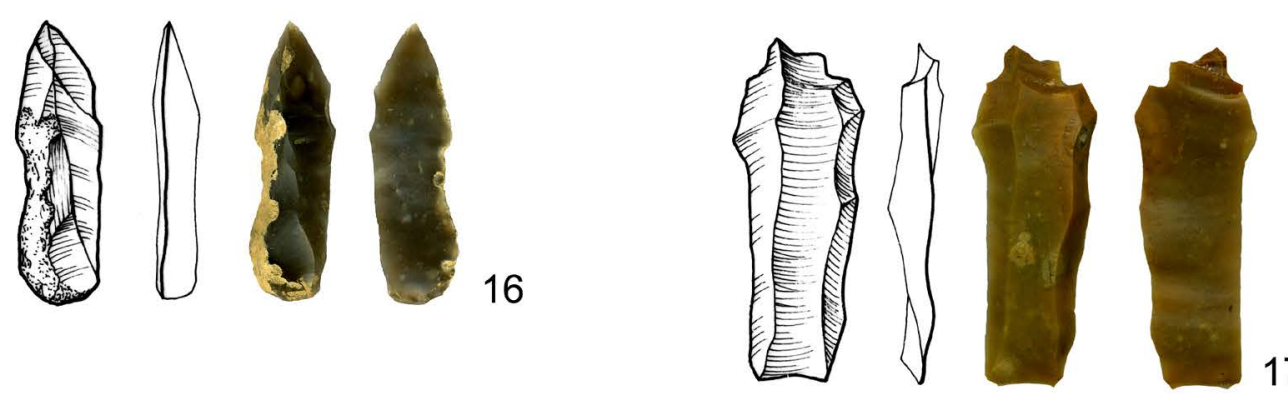

17
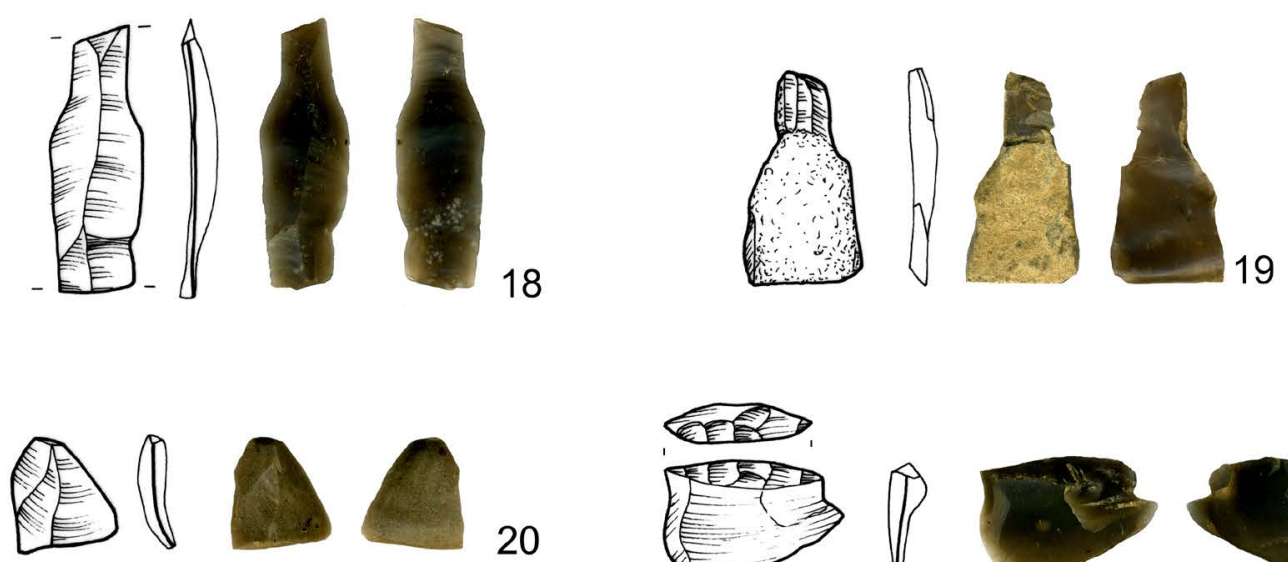

20
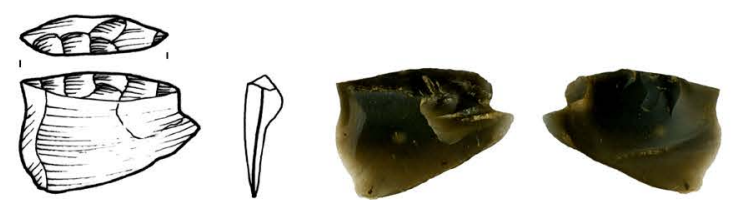

21
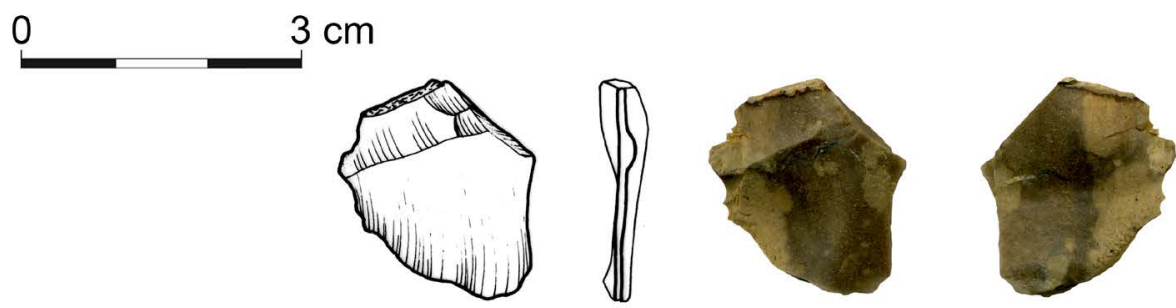

22

Figure 4. Weklice, Elbląg County. Flint artefacts: 14. flake fragment; 15. initial flake; 16. partially initial blade; 17. crested blade; 18. blade with scars on the dorsal surface; 19 . partially initial flake; 20. microflake with negative flake scars on the dorsal surface; 21. flake with negative flake scars on the dorsal surface; 22. flake with negative flake scars on the dorsal surface. (Drawing by E. Gumińska, E. Pazyna and D. H. Werra. Photo by M. Natuniewicz-Sekuła.) 


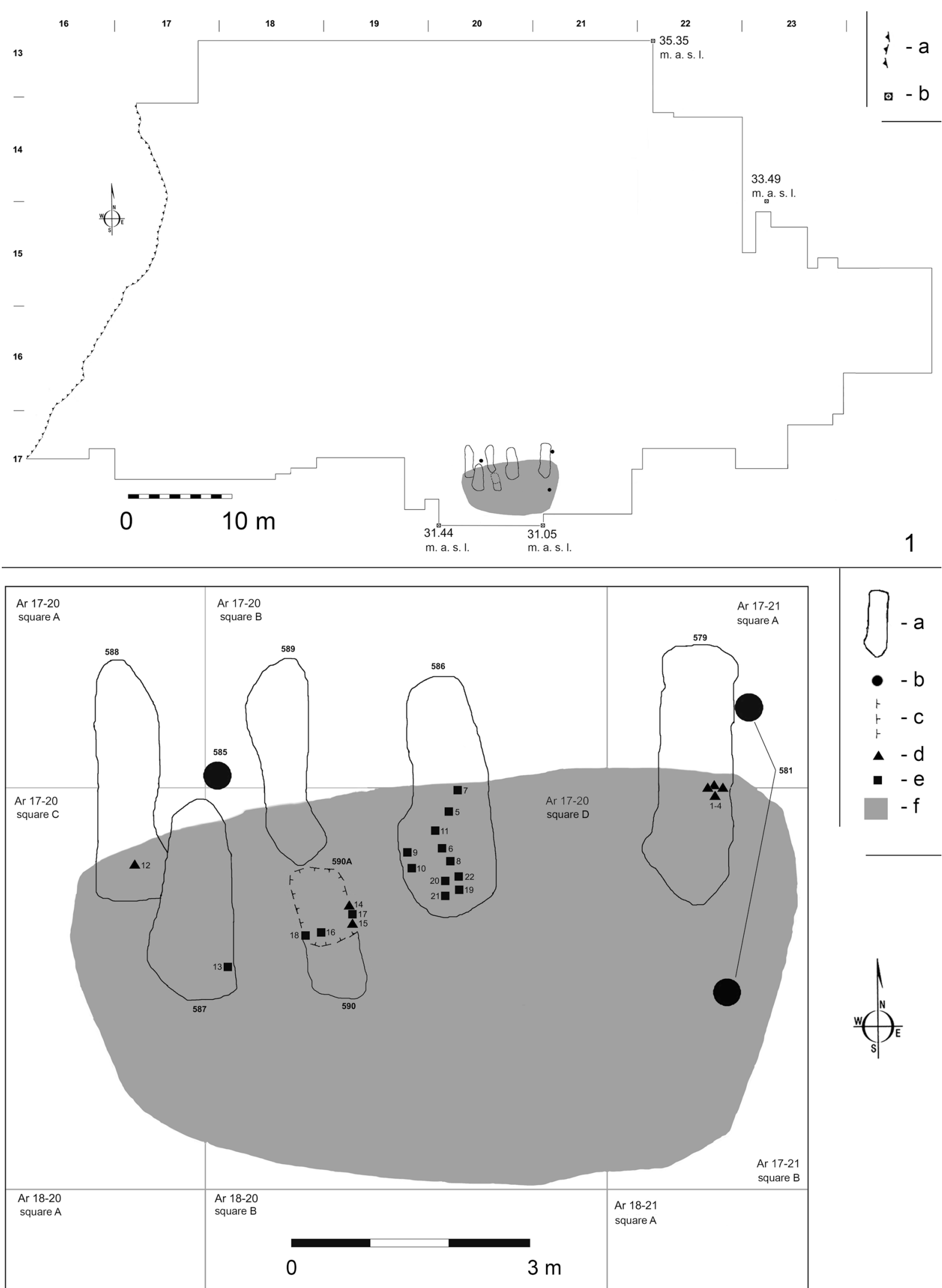

Figure 5. Weklice, Elblagg County. 1. the excavated fragment of the site; the locations of flint artefacts found on the site are marked: a. gravel mine face; b. geodesic benchmarks; 2. flint artefacts scatter within graves and features of the Wielbark culture and the conjectured boundary of the occupation layer [100A-B ]: a. Wielbark culture inhumation graves; b. Wielbark culture urn cremation graves; c. feature 590A (ancient robbery trench leading to grave 590); d. flints found in the grave fill; e. flints found in layer [100B] below the grave-pit bottom; f. conjectured boundary of the occupation layer [100A-B ]. (Drawing by M. Natuniewicz-Sekuła.) 
It should be noted that the area where the discoveries were made is situated on the southernmost edge of the cemetery (in the southern part of the cemetery there are primarily graves from the younger stage of Late Roman Period with a predominance of grave inventories well-dated to phase C2 of Late Roman Period), at the bottom of an esker hill on which the cemetery was created. At present, the elevation difference between the top and the bottom of the hill exceeds four meters (see Figure 5(1)). This is reflected in the depth of the graves at the foot of the excavated area, which are discovered approximately 2 to 3 meters down from ground level and were covered by a layer of solifluction (no. [100]; according to the adopted research methods the layer numbers, as opposed to feature numbers, are given in square brackets. This system is used consistently throughout the paper), which defines the original level at which the cemetery was used during the Roman Period, then layer no. [80] (a layer from the Early Middle Ages), and layers of plough soil, respectively nos. [75] and [77] (modern until the 19th and the beginning of the 20th centuries, and contemporary until the 1960s) as well as no. [72] - top soil.

A stratigraphic method of exploration was used at the site; the layers were studied according to their natural or anthropogenic layout. Features at the level of detection were negatively explored. Prior to the excavations under discussion all graves from the Wielbark culture had been dug into natural geological layers, however on numerous occasions the top part of the graves was reached a slightly higher level in layer no. [100], i.e. the solifluction layer containing fine powdery dark yellow sand, with spots of pale yellow and greyish sand. That layer contains numerous bands of reddish hardpan, clayed in places, consisting of dense coarse-grained sand. Also, contained in that layer are single stones (these stones have mostly natural characteristics associated with their geology, however, they may also be intentional markings of the destroyed urn cremation and inhumation graves. In several cases when graves were undamaged, similar stones were found as urn covers, as single ones or small pavements, or marked the pits of inhumation graves) and numerous small pieces of charcoal, cremated and non-cremated human bones, as well as artefacts from the Wielbark culture coming from destroyed graves, found without their context. In the top part of this layer there are brownish precipitations mixed with inclusions belonging to an occupation level from the Early Middle Ages (no. [80]) situated directly over layer no. [100].

While uncovering the outlines of the inhumation graves in 2013, a slightly different stratigraphic situation was noted. The esker where the cemetery is located is composed of heterogeneous glacial drift from the Baltic glaciations. The esker is mostly built of layers and lenses of different grades of sands and gravels, stones and boulders, but also clay and numerous bands of hardpan inclusions, usually in an irregular arrangement. This non-uniform substratum results in major differences in interpretations making it difficult to capture patterns in the features and layers in the field, as well as state of preservation of the human bones and other discovered artefacts (more on the geomorphology position cf. Natuniewicz-Sekuła \& Okulicz-Kozaryn 2011: 13-15). A portion of the features were dug into layer no. [100A] consisting of loose and medium dense dark yellow sand, heavily mixed with reddish sand and very dense hardpan inclusions. There were numerous concentrations of brownish decaying organic material and charcoal. This layer was not found on the entire surface of the trench, and was captured on the plan only around some of the graves (see Figures 5(2) and 6(1)). Given the high saturation levels of organic matter and charcoal it was initially assumed to be evidence of archaeologically intangible remains of funeral rites from Wielbark culture communities. However, exploration of various graves revealed that the layer continued below the bottom of the grave pits, changing its structure to pale, fine yellow sand mixed with small grained greyish sand with numerous small pieces of charcoal and hardpanband inclusions along the west-east axis. This may be clearly seen in the hardpan found between the stratified layers, nos. [100A] and [100B] (see Figure 6(2,3)). Complete examination of this layer in the 
space between the graves was impossible due to poor weather conditions. While the graves and the discussed layer were being unearthed a severe hailstorm flooded the trench completely, and destroyed the over 2.5 meters-high profiles, resulting in landslides of several tons of soil. Once the water and the mud had been removed, part of the landslide was removed manually under the tallest profiles (which were still standing) in order to protect the site from further damage. With the deadline of the excavation season approaching, the inhumation graves of the Wielbark culture became the priority for exploration. The remaining parts of the trench were secured (including the layers in the space between the graves) for future excavation. During the exploration of graves, aside from the artefacts associated with the Wielbark culture discovered in the grave fills as well as directly underneath (in described layers nos. [100A] and [100B]), a collection of flint specimens discussed in this article was found.
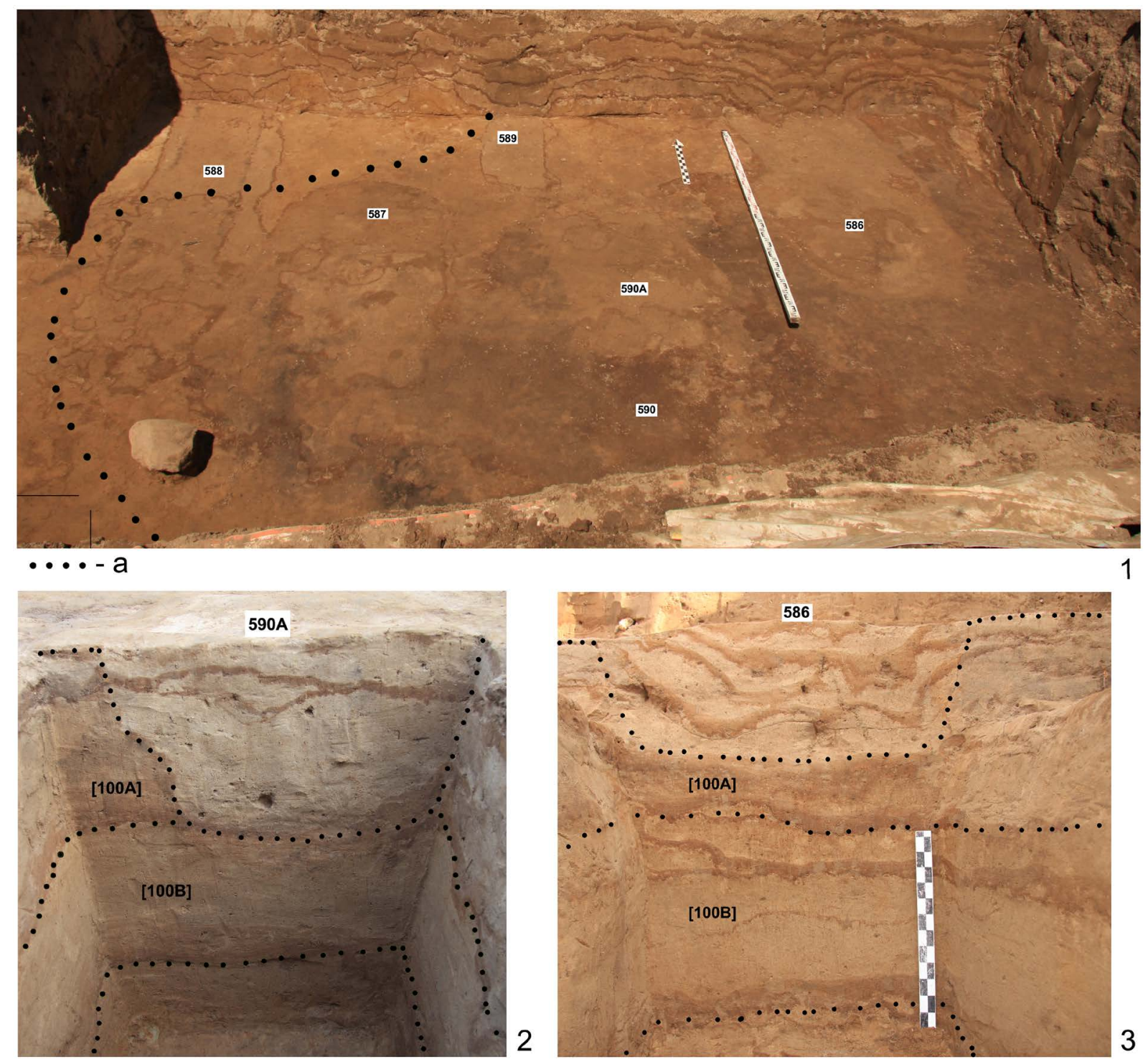

Figure 6. Weklice, Elbląg County. 1. level of detection of graves and features in the exposed area of the trench; a. conjectured boundary of the occupation layer [100A]; 2. cross-section of feature 590A with visible layers [100A] and [100B]; 3. cross-section of grave 586 with visible layers [100A] and [100B]. (Photo by G. Czopowicz and M. Natuniewicz-Sekuła.) 


\section{Analysis of flint materials}

Flint materials have no clear typological cultural context. Therefore, all the flint materials were analysed together. Table 1 shows the overall characteristics of the typological raw materials.

The analysed flint material is characterized by a broad variety of colour, translucence and lustre in the raw material. Besides the retouched blade, made most likely from Cretaceous flint - Volhynian flint (see Figure 3(12)) - the other specimens were made from local raw materials (Baltic Erratic flint, Pomeranian flint). It is worth to noting that three specimens were made from raw material characterised by a significant lack of transparency and opacity, which resembles Turonian flint (See Figures 3(9) and 4(20,22)). Full identification requires petrographic analysis.

No cores were found in the analysed material and only two specimens can be connected with the stages of core preparation: a secondary crested blade (see Figure 2(5)) and a crested blade (see Figure 4(17)). A set classified as semi-raw material contained flakes (12 specimens, see Figures 2(1,3,6,7), 3(9,11), and 4(14,15,19-22)), and blades (six specimens, see Figures 2(2,4), 3(10,13), and 4(16,18)). A set classified as tools contained an endscraper made from Baltic Erratic flint, discovered in layer [100B] under grave 586 (Figure 2(8)), and a retouched blade - found in grave 588 (Figure 3(12)).

The overall typology and material types as shown in Table 1 suggests the presence of the blade technique (see Figures 2(2,4,5), 3(10,12,13), and 4(16-18)) and the flaking technique (see Figures 2(1,3,6,8), 3(9,11), and 4(14,15,19-22)). Elements of a double striking platform (see Figure 3(13)) and the bipolar techniques (see Figure 2(7)) were observed. Most specimens are damaged or have missing platforms (see Figures 2(2,5), 3(10), and 4(18)). The ones that have been preserved vary widely. Among the specimens we noted platform edge trimming (see Figure 3(13)), the "bird's eye" type - l'oeil d'oiseau (see Figure 2(1)), and with a visible "lip" (see Figure 3(13)). The blades are straight (see Figures 3(10), and 4(16,18)) as well as curled (see Figures 2(2), and 3(13)). It is difficult to observe the regularities concerning the maximum width of the blades, which range from 6 to $14 \mathrm{~mm}$ (6 specimens).

Those characteristics make it impossible to identify any shared principles in terms of flint reflection technique. One specimen illustrates the presence of a bipolar technique (see Figure 2(7)), another suggests so-called direct percussion (see Figure 2(1)). The endscraper from the described collection bears signs suggesting that edge trimming was used (see Figure 2(8)). One of the blades and the retouched blade (see Figure 3(12,13)) bear characteristics produced by the use of the pressure technique.

The retouched blade (see Figure 3(12)), the most distinctive tool in the presented collection, deserves to be discussed separately. The specimen has the following dimensions: length $118 \mathrm{~mm}$, width $17 \mathrm{~mm}$, thickness $9 \mathrm{~mm}$, with multi-step retouching; the blade was created from Cretaceous flint, probably reflected from a single striking platform core using the pressure technique (Migal 2002: 261; Libera \& Zakościelna 2006: 136).

The dimensions, the raw material and the presence of retouching (which imitates in parts laminar retouch) makes it possible to link the specimen with production by Eneolithic communities (Zakościelna 1996: 105). Blades made from this type of Cretaceous flint showing evidence of multi-retouching and partly laminar retouch are known from the LublinVolhynian culture (Kaczanowska \& Lech 1977: 20; Kulczycka-Leciejewiczowa 1979: 138, 142, fig. 70:1; Zakościelna 1996: 103; Libera \& Zakościelna 2013: 218-220). Instances of laminar and pseudo-laminar retouch are also known from flint materials of communities of the Funnel Beaker culture (Młynarczyk 1982: table IX.3), the Corded Ware culture and the Mierzanowice culture (Libera \& Zakościelna 2013: 220-227). 
In the flint materials from the Funnel Beaker culture found in the Polish Lowlands we find - among others - retouched blades and endscrapers made from Volhynian Flint (MałeckaKukawka 2001: 75-77, tables 24.8, 25.10, 26.4, 25.8; Papiernik \& Rybicka 2002: 108-115, fig. 86-88). The closest analogies in terms of raw materials in retouched blades - which correspond in shape and size to the specimens from Weklice - are known from site 3 at Rożental, Tczew district (Felczak 1984: 33-34; personal communications with Olgierd Felczak in November 2014). It is worth noting that on the site, five blades attributed to the Funnel Beaker Culture (16 cm long) made from Volhynian Flints were found, among other flint finds.

A direct analogy for this type of retouched blade made of Volhynian Flint with laminar retouch can exist in materials from a cemetery at Złota, Sandomierz district. It was found in a grave connected with the activities of the Lublin-Volhynian culture communities (Kaczanowska \& Lech 1977: 20; Kulczycka-Leciejewiczowa 1979: 142).

Macrolithic retouched blades (endscrapers and perforators on a retouched blade) made mainly from Volhynian and Świeciechów (grey-white spotted) flint are known from graves of the Funnel Beaker culture (the southeastern group; Libera \& Zakościelna 2006: 138-149). The specimen from Weklice meets the standard metrics designated for retouched blades as proposed by Libera \& Zakościelna (2006: 142).

The closest analogies for the retouched blades from the Funnel Beaker culture graves, observed further in the north-east, are known from Krzywośnity, Łosice district, site 1 and Żerocin, Biała Podlaska district, site 3 (Bienia 2003: 36-37; Libera \& Zakościelna 2006: table 1, fig. 15).

Given the current state of knowledge, it would be impossible at this point to identify the exact prehistoric culture of origin for the finds with any degree of certainty. However, it is possible to indicate a general affiliation for the individual specimens. The secondary crested blades and other blades can be connected to Mesolithic inventories (see Figures 2(5), and $3(10,13)$ ). The endscraper (see Figure 2(8)) is characteristic of Final Palaeolithic and Mesolithic inventories. The retouched blade (see Figure 3(12)) can be most likely linked with Neolithic inventories (possibly the Lublin-Volhynian culture).

It should be noted that the chronology of the presented material ranges from the Final Palaeolithic to the Early Bronze Age.

\section{Conclusions}

The stratigraphic situation mentioned in the introduction made it difficult to draw clear conclusions concerning the character, the chronology of the layer beneath the graves, and the collected flint materials from the discussed layer and the Wielbark culture graves. At this stage it is difficult to recognize clearly whether the analysed material should be linked to the Wielbark culture or if the material is a remnant of older cultures.

The presence of the flint artefacts at the Roman Period cemetery gives rise to several possible interpretations. 1 . The flints might be residual artefacts, introduced into the fill of the Wielbark culture graves when those were cut into an older stratum; 2. the flints may come from an earlier period, and may have been deliberately inserted into the graves during the Roman Period; 3. the flints may be remains of flint knapping activity of a Wielbark culture community (Bogucka-Slaska 1975: 211, 215; Libera \& Florek 2014: 49).

It is worth noting that while the cemetery remained in use, and probably much earlier as well, the landscape of the area was quite different from today. The esker on which the necropolis was founded was much higher and steeper, meaning that the place would have been a convenient spot for seasonal settlement at its foot. The coastline of the Vistula Lagoon (now the Drużno Lake) extended almost to the edge of the Elbąg Upland at the time 
(Kasprzycka 1998: 44-45; 1999). In addition, it must be mentioned that several settlements were recorded during the surveys to the south of the cemetery (within the then shoreline of Drużno lake). They are dated on the basis of the pottery to be not earlier than the early Iron Age (Natuniewicz-Sekuła \& Okulicz-Kozaryn 2011: 11). None of them has so far been excavated. According to other sources, discoveries have been made at Weklice (at an unidentified location) of a bronze axe from the III Bronze Age and a necklace from the early Iron Age (Kleemann 1938: table VIA).

This said, it cannot be ruled out that individual specimens may have been products of activities of Wielbark culture communities, especially with regard to the flint flakes and flint waste, which do not have any obvious scratches, retouching marks or other kinds of damage to identify them as fire-stones. The exceptions is one artefact with this type of marks (See Figure 3(21)), which could have been caused by this kind of treatment. This problem cannot be resolved without use-wear analysis (see Table 1(1-4), Figure 2(1-4)). The presence of flint among the finds dated from the pre-Roman and Roman Period was observed, among others, on the multicultural cemetery at Nowy Targ, site 6, Sztum district. The 66 specimens collected there were made from Baltic Erratic or Pomeranian flint, mainly natural concretions and their fragments and splintered pieces (Gawrońska 2013: 295-296). Similar situations showing the presence of flints dating to the Late Roman Period were recorded at cemeteries at Mil'ne, site 5 (Мильне, Тернопільська обл.) in Western Ukraine (Stroceń \& Stroceń 2014), and at Neizats (Нейзац, today: Красногірське) in Crimea (Mączyński 2014).

The interpretation that flint specimens from an earlier period were placed in the graves is the most likely one in the case of the retouched blade made from Cretaceous Flint in grave 588 (see Figure 3(12)). This specimen differs from typical lithic flint materials from the Polish lowlands in terms of raw materials, dimensions, and morphology. In that area flint artefacts are known for being made from imported raw materials. Flint finds made from Volhynian flint have been made in the area of Gostyń Lake District (Papiernik \& Rybicka 2002: 108-115, fig. 86-88), on Chełmno land (Małecka-Kukawka 2001: 75-77, tables 24.8, 25.10, 26.4, 25.8) and the Eastern Pomerania (see Felczak 1984: 34).

It cannot be ruled out that the presence of the retouched blade found in the Wielbark culture grave was the result of intentional activities the Wielbark community. It is likely to have been the result of exchange and distribution during the Roman Period, imported into the Polish northeastern area and then deliberately placed in the grave. Isolated instances of flint tools and flakes from earlier periods being inserted into graves during the Roman Period are known in the Przeworsk culture (eastern zone), and among others at Nadkole, site 2, Węgrów district, grave 88, and also in Scandinavia (Andrzejowski 1998: 37, 86, table LIV.9). Numerous similar cases have been recorded in the regions of the Czerniachov and Sarmatian cultures in the geological regions of origin for the material from which the specimen from grave 588 was made (see for example, Kropotkin 1988; Hrapunov 2002). In this grave, a buckle close to type AB9 according to Madyda-Legutko (1987) and an eight-shape amber bead were found, which makes it possible to date the find in general terms to phases C1b-C2 of the Late Roman Period. It should also be emphasized that all the graves discovered at this part of the cemetery may be dated to the Late Roman Period, and the finds from their inventories reflect a south-east connection, and are therefore contemporaneous with the already developed Czerniachov culture.

In the Bronze and Iron Ages, the long-standing tradition of placing flints into graves as grave goods was continued (Bogucka-Slaska 1975: 215-219; Balcer 1997; Lech \& Piotrowska 1997; Mogielnicka-Urban 1997; Piotrowska 1997; 2000; Kłosińska 2012: 135, 150-151; Gawrońska 2013: 295-296; Lech et al. 2015).

Prehistoric societies were most likely aware of a connection between flint products and their ancestors (Piotrowska 2000: 303). In the graves, we find tools as well as unworked 
specimens (Balcer 1997: 314). It cannot be ruled out that the presence of flint in some graves at Weklice may be accidental, but in some cases we can be almost certain that some of the flint finds were placed in the graves intentionally, and those who did it were aware of their uniqueness. This applies especially to the retouched blade discovered in grave 588. It is an exceptional find in this region, and we are inclined to accept that it held some special significance in the ceremonial rituals held during that particular burial (see Piotrowska 2000: 315).

A comprehensive interpretation of the circumstances of intentional depositions of flint material in the cemetery will only be possible following further comprehensive analysis of the area between the graves and an examination of layer [100A-B]. It is worth noting that no other signs of settlements from the Stone Age to the early Bronze Age have been found so far in the immediate vicinity of Weklice. However, prehistoric settlement in the Elbląg Upland from the Final Palaeolithic until Early Bronze Ages is confirmed by materials from Suchacz, site 1 (Januszek 2012), Janów, site 1 (Wąs 2012) or Elbląg-Modrzewina (Janek 2003), all in the Elbląg district.

\section{Acknowledgements}

The main issues of this paper were presented at the conference "On the Rocks" International Symposium on Knappable Materials (7-12. IX. 2015, Barcelona, Spain; Werra \& Natuniewicz-Sekuła 2015). A Polish version of the text was published in volume 65 of "Wiadomości Archeologiczne" (cf. Natuniewicz-Sekuła \& Werra 2014).

We would like to thank for consultation to assistant professor Zofia Sulgostowska, from IAE PAN, professor Jacek Lech from Cardinal Stefan Wyszyński University in Warsaw and assistant professor Jerzy Libera from Maria Curie-Skłodowska University in Lublin. Also we would like to kindly thank Olgierd Felczak from Archaeological Museum in Gdańsk and Maria Michniewicz from Bio- and Archaeometry Laboratory, Institute of Archaeology and Ethnology Polish Academy of Sciences for wood botanical determines.

Research conducted under the grant from the National Science Centre no. 2013/11/D/HS3/02473). The publication was created with financial support from the Institute of Archaeology and Ethnology Polish Academy of Science in the competition Adulescentiaest tempus discendi in 2015 (10/ATD5/MN/2015). The authors would like to thank Magdalena Srienc for translating this article. The special thanks to Piotr Szymczak for improving the English version of the text and for clarification our ideas.

\section{References}

Andrzejowski, J. 1998, Nadkole 2. A Cemetery of the Przeworsk Culture in Eastern Poland. Monumenta Archaeologica Barbarica Vol. 5, Instytut Archeologii i Etnologii Polskiej Akademii Nauk, Państwowe Muzeum Archeologiczne w Warszawie, Kraków, 268 p.

Balcer, B. 1997, Z badań nad krzemieniarstwem w epokach metali. In: Z badań nad krzemieniarstwem epoki brązu $i$ wczesnej epoki żelaza. Materiały sympozjum zorganizowanego w Warszawie 20-22 października 1994 r. (Lech, J. \& Piotrowska, D., Eds.), Prace Vol. 2, Polska Akademia Nauk. Komitet Nauk Pra- i Protohistorycznych. Warsaw: p. 303-317. (in Polish) ("Research into the flint industry in the metal ages”)

Bienia, M. 2003, Czasy prehistoryczne. In: Pótnocna Lubelszczyzna od pradziejów po okres nowożytny (Banasiewicz-Szykuła E., Ed.), Skarby z przeszłości Vol. 5, Wojewódzki Oddział Służby Ochrony Zabytków, Lublin: p. 23-72. (in Polish) (“Prehistoric Times”) 
Bogucka-Slaska, E. 1975, Uwagi o krzemieniarstwie poneolitycznym na Pomorzu Środkowym. Koszalińskie Zeszyty Muzealne, 5: 205-219. (in Polish) ("Remarks concerning postneolithic flint materials from Central Pomeranian”)

Felczak, O. 1984, Rożental, gm. Pelplin, woj. gdańskie, stanowisko 1 i 3. Informator Archeologiczny, (Konopka, M., Ed.) (Warsaw), 18: 33-34. (in Polish) ("Rożental, Pelplin district, Gdańsk voivodeship, site 1 and 3")

URL: http://bazhum.muzhp.pl/media//files/Informator_Archeologiczny_badania/Inform ator_Archeologiczny_badania-r1984-t18/Informator_Archeologiczny_badania-r1984t18-s33-34/Informator_Archeologiczny_badania-r1984-t18-s33-34.pdf

Gawrońska, J. 2013, Materiały krzemienne z wielokulturowego cmentarzyska w Nowym Targu stan. 6, gm. Stary Targ. In: Wielokulturowe cmentarzysko w Nowym Targu stan. 6, gm. Stary Targ (Fudzińska, E. \& Fudziński, P., Eds.), Muzeum Zamkowe w Malborku, Malbork: p. 293-328. (in Polish) ("Flint materials from multicultural cemetery in Nowy Targ, Site 6, Stary Targ commune”)

Hrapunov, I.N. (Храпунов, И.Н.) 2002, Могильник Дружное (III-IV вв. нашей эры).Monumenta Studia Gothica Vol. 2, Wydawnictwo Uniwersytetu Marii CurieSkłdowskiej w Lublinie, Lublin, 313 p. (in Russian) ("The Cemetery of Droozhnoye ( $3^{\text {rd }}-4^{\text {th }}$ centuries)")

Janek, D. 2003, Osiedle kultury łużyckiej w Elblągu-Modrzewinie w świetle zachowanych i dostępnych dziś źródeł archeologicznych. The manuscript of MA thesis in the library of Institute of Archaeology, Warsaw University, Warsaw, 151 p. (in Polish) ("The settlement of Lusatian Culture at Elbląg-Modrzewina in light of the preserved and today available archaeological sources”)

Januszek, K. 2012, Materiały krzemienne nawiązujące do wyrobów z późnego paleolitu z Suchacza, stan. 1, woj.warmińsko-mazurskie. Światowit, 7(48): 67-71 (Fasc. B (20062008): Archeologia pradziejowa i średniowieczna. Archeologia Polski). (in Polish) ("Flint materials referring to the Late Paleolithic from Suchacz site 1, WarmianMasurian Voivodeship”)

Kaczanowska, M., Lech, J. 1977, The Flint Industry of Danubian Communities North of the Carpathians. Acta Archaeologica Carpathica, 17: 5-28.

Kasprzycka, M. 1998, Mierzeja Wiślana - powstanie, rozwój cieśniny. In: Adalbertus. Wyniki programu badań interdyscyplinarnych (Urbańczyk, P., Ed.), Adalbertus. Tło kulturowogeograficzne wyprawy misyjnej św. Wojciecha na pogranicze polsko-pruskie Vol. 1, Warsaw: p. 35-48. (in Polish) ("Vistula Spit - creation, development of the strait")

Kasprzycka, M. 1999, Tło paleogeograficzne osadnictwa Żuław Elblaskich w pierwszym tysiacleciu naszej ery. In: (Urbańczyk, P., Ed.) Adalbertus. Tło kulturowo-geograficzne wyprawy misyjnej św. Wojciecha na pogranicze polsko-pruskie Vol. 5, Instytut Archeologii i Etnologii Polskiej Akademii Nauk, Warsaw, 194 p. (in Polish) ("The paleogeographical background of Elbląg Żuławy settlements in the first millennium AD”)

Kleemann, O. 1938, Die Funde des Elbinger Kreisesim Prussia-Museum. Elbinger Jahrbuch, 15: 23-33. (in German) ("The finds of the Elbinger Circle in the Prussia Museum") 
Kłosińska, E.M. 2012, Przyczynek do badań nad występowaniem przedmiotów krzemiennych, kamieni i skamielin w grobach ludności kultury łużyckiej na Lubelszczyźnie. Materiały i Sprawozdania Rzeszowskiego Ośrodka Archeologicznego, 33: 135-154. (in Polish) ("Contribution to the study of the occurrence of flint items, rocks and fossils in the Burias of the Lusatian culture in the Lublin region”)

Kropotkin V.V. (Кропоткин, В.В.) 1988, Могильники черняховской культурь. Москва, 184 p. (in Russian) (“The cemeteries of Czerniachov Culture”)

Kulczycka-Leciejewiczowa, A. 1979, Młodsze kultury kręgu naddunajskiego na ziemiach polskich. In: Prahistoria ziem polskich II: Neolit (Hensel, W., \& Wiślański, T., Eds.), Ossolineum, Wrocław-Warsaw-Kraków-Gdańsk: p. 95-164. (in Polish) (“Middle Neolithic Danubian communities in Poland")

Lech, J., \& Piotrowska, D., Eds., 1997, Z badań nad krzemieniarstwem epoki brąu $i$ wczesnej epoki żelaza. Materiały sympozjum zorganizowanego w Warszawie 20-22 października 1994 r. Prace Vol. 2, Polska Akademia Nauk. Komitet Nauk Pra- i Protohistorycznych, Warsaw, 356 p. (in Polish) ("Studies of Flint-mining and Flint-working in the Bronze and Early Iron Ages. Proceedings of the flint sympodium held in Warsaw 20-22 October 1994”)

Lech, J., Piotrowska, D., \& Werra, D.H. 2015 Between economy and symbol: flint in the Bronze Age in East Central Europe. In: Forging Identities. The Mobility of Culture in Bronze Age Europe Report from a Marie Curie project 2009-2012 with concluding conference at Aarhus University, Moesgaard 2012, Volume 1 (Suchowska-Ducke, P., Scott Reiter, S., \& Vandkilde, H., Eds.), Archaeopress, Oxford: p. 221-229.

Libera, J., Florek, M. 2014, O używaniu krzemienia we wczesnym średniowieczu. In: Badania archeologiczne w Polsce środkowowschodniej, zachodniej Białorusi i Ukrainie w roku 2013: streszczenia referatów XXX konferencji (Libera, J., \& Zakościelna, Z., Eds.), Institute of Archaeology UMCS and Muzeum Lubelskie in Lublin, Lublin: p. 4950. (in Polish) ("The use of flint in Early Middel Ages")

Libera, J. \& Zakościelna, A. 2006, Inwentarze krzemienne z grobów grupy południowowschodniej kultury pucharów lejkowatych. In: Idea megalityczna w obrządku pogrzebowym kultury pucharów lejkowatych (Libera, J., \&Tunia, K., Eds.), Institute of Archaeology an Ethnology Polish Academy of Science and Institute of Archaeology UMCS, Lublin-Kraków: p. 135-169. (in Polish) ("Flint inventories from the Graves of the South-Eastern group of the Funnel Beaker culture”)

Libera, J., \& Zakościelna, A. 2013, Retusz rynienkowaty w eneolicie i wczesnej epoce brązu na ziemiach polskich. In: Retusz-jak i dlaczego? „, Wieloperspektywiczność elementu twardzowego" / Retouch - how and what for? Multi-perceptiveness of stone tools (Nowak, M., Stefański, D., \& Zając, M., Eds.), Prace Archeologiczne Vol. 66. Studia, Kraków: p. 215-239. (in Polish) ("Laminar retouch in the Eneolithic and Early Bronze Age in the territory of Poland”)

Libera, J., \& Zakościelna, A., Eds. 2014, Badania archeologiczne w Polsce środkowowschodniej, zachodniej Białorusi i Ukrainie w roku 2013: streszczenia referatów XXX konferencji. Institute of Archaeology UMCS and Muzeum Lubelskie in Lublin, Lublin, 66 p. (in Polish) ("Archaeological researches in south-east Poland, western Belarus and Ukraine in 2013: abstracts of lectures of XXX conference") 
Madyda-Legutko, R. 1987, Die Gürtelschnallen der römischen Kaiserzeit und der frühen Völkerwanderungzeitim mitteleuropäischen Barbaricum. BAR International Series Vol. 360, Archaeopress, Oxford, 233 p. (in German) (“ The belt buckles of Roman Period and early Migration Period in the Central European Barbaricum”)

Małecka-Kukawka, J. 2001, Między forma a funkcją. Treseologia neolitycznych zabytków krzemiennych z ziemi chetmińskiej. Wydawnictwo Uniwersytetu Mikołaja Kopernika w Toruniu, Torun, 254 p. (in Polish) ("Between Form and Function. Traseological Analysis of the Neolithic Flint Assemblages from Chełmno Land")

Mączyński, P. 2014, Kilka uwag o zabytkach krzemiennych pochodzących z cmentarzyska Nejzacna Krymie. In: Badania archeologiczne w Polsce środkowowschodniej, zachodniej Białorusi i Ukrainie w roku 2013: streszczenia referatów XXX konferencji (Libera, J., \& Zakościelna, A., Eds.), Institute of Archaeology UMCS and Muzeum Lubelskie in Lublin, Lublin: p. 28-29. (in Polish) ("Remarks concerning flints from cemetery in Najzac, Crimea”)

Migal, W. 2002, Zamysł technologiczny wióra krzemiennego Winiar, gm. Dwikozy. In: Krzemień świeciechowski w pradziejach. Materiaty z konferencji w Ryni, 22-24.05.2000 (Matraszek, B., \& Sałaciński, S., Eds.), Studia nad Gospodarką Surowcami Krzemiennymi w Pradziejach Vol. 4, Semper, Warsaw: p. 255-266. (in Polish) ("Technoloical analysis of Winiary blade")

Młynarczyk, H. 1982, Materiały krzemienne z grobowców kujawskich w Sarnowie, Gaju, Leśniczówce i Wietrzychowicach. Światowit, 35: 55-93. (in Polish) ("Flint materials of Kuyavian burrows in Sarnowo, Gaj, Leśniczówka and Wietrzychowice”)

Mogielnicka-Urban, M. 1997, Rola krzemienia w obrzędowości ludności kultury łużyckiej na przykładzie cmentarzyska w Maciejowicach, woj. siedleckie. In: Z badań nad krzemieniarstwem epoki brązu $i$ wczesnej epoki żelaza. Materiały sympozjum zorganizowanego w Warszawie 20-22 października 1994 r. (Lech, J., \& Piotrowska, D., Eds.), Prace II, Polska Akademia Nauk. Komitet Nauk Pra- i Protohistorycznych. Warsaw: p. 277-287. (in Polish) ("The role of flint in the rites of Lausitz culture people, exemplified by the cemetery at Maciejowice, Siedlce voiv.”)

Natuniewicz-Sekuła, M., Okulicz-Kozaryn, J. 2011, Weklice.A Cemetery of the Wielbark Culture on the Eastern Margin of Vistula Delta (Excavations 1984-2004). Monumenta Archaeologica Barbarica Vol. 17, Fundacja Monumenta Archaeologica Barbarica, Instytut Archeologii i Etnologii Polskiej Akademii Nauk, Państwowe Muzeum Archeologiczne w Warszawie, Warsaw, 431 p.

Natuniewicz-Sekuła, \& M. Werra, D.H. 2014, Materiały krzemienne z cmentarzyska kultury wielbarskiej w Weklicach, stan. 7, pow. elbląski. Wiadomości Archeologiczne, 65: 197210. (in Polish) ("Flint artefacts from the Wielbark Culture cemetery at Weklice, site 7, Elbląg County”)

Papiernik, P.\& Rybicka, M. 2002, Annopol. Osada kultury pucharów lejkowatych na Pojezierzu Gostynińskim. Wydawnictwo Fundacji Badań Archeologicznych imienia Profesora Konrada Jażdżewskiego 6, Łódź, 214 p. (in Polish) (“Annopol. Funnel Beaker Culture settelemnt at Gostynin Lakeland ”) 
Piotrowska, D. 1997, Problem występowania materiałów krzemiennych na cmentarzysku kultury łużyckiej w Gąsawie, woj. Bydgoskie. In: Z badań nad krzemieniarstwem epoki brązu i wczesnej epoki żelaza. Materiały sympozjum zorganizowanego w Warszawie 2022 października 1994 r. (Lech, J., \& Piotrowska, D., Eds.), Prace Vol. 2, Polska Akademia Nauk. Komitet Nauk Pra- i Proto historycznych, Warsaw: p. 259-275. (in Polish) ("The issue of flint materials at the Lausitz culture cementary at Gąsawa, Bydgoszcz voiv.”)

Piotrowska, D. 2000, Krzemienie w grobach z pólpopielnicowych: przypadek czy rytuał? In: Kultura symboliczna kręgu pól popielnicowych epoki brąu $i$ wczesnej epoki żelaza $w$ Europie Środkowej (Gediga, B., \& Piotrowska, D., Eds.), Prace Komisji Archeologicznej Vol. 13,Biskupińskie Prace Archeologiczne 1, Warsaw-WrocławBiskupin: p. 293-330. (in Polish) ("Flints in the graves of the Urnfield culture: coincidence or ritual?”)

Stroceń, B., \& Stroceń, L. 2014, Milne 5 - nowe cmentarzysko z późnego okresu rzymskiego na pograniczu wołyńsko-podolskim. In: Badania archeologiczne w Polsce środkowowschodniej, zachodniej Białorusi i Ukrainie w roku 2013: streszczenia referatów XXX konferencji (Libera, J., \& Zakościelna, A., Eds.), Institute of Archaeology UMCS and Muzeum Lubelskie in Lublin, Lublin: p. 26. (in Polish) ("Milne 5 - a new cemetery from the Late Roman Period on the border between Volhyn and Podolia")

Wąs, M. 2012, Materiały krzemienne ze stanowiska Janów Pomorski 1. In: Studia nad Truso / Truso Studies I: Janów Pomorskistan. 1. Wyniki ratowniczych badań archeologicznych w latach 2007-2008/Janów Pomorski site 1. Archaeological Rescue Excavations in 2007-2008/Od paleolitu do wczesnego okresu wędrówek ludów/From the Paleolithic to the early migration period (Bogucki, M., \& Jurkiewicz, B., Eds.), Muzeum Archeologiczno Historyczne w Elblągu, Elbląg: p. 39-50. (in Polish) ("Flint materials from the site Janów Pomorski 1”)

Werra, D.H., \& Natuniewicz-Sekuła, M. 2015, Flints in Iron Age graves: flints from the cemetery at Weklice, Elbląg County, Elbląg District, Northern Poland. In: International Symposium on Knappable Materials "On the Rocks", 7-11 September 2015, Barcelona, Abstracts (Mangado, X., Crandell, O., Sánchez, M., \& Cubero, M., Eds.), Universitat de Barcelona, Barcelona: p. 66.

Zakościelna, A. 1996, Krzemieniarstwo kultury wolyńsko-lubelskiej ceramiki malowanej. Lubelskie Materiały Archeologiczne Vol. 10,Wydawnictwo Uniwersytetu Marii CurieSkłodowskiej, Lublin, 266 p. (in Polish) ("Flint-Working of the Volhyn-Lublin Painted Pottery Culture”) 